\title{
Molecular characterisation of hepatitis B virus in the resident Chinese population in Panama City
}

\author{
Alexander Augusto Martinez ${ }^{1,2,3}$, Yamitzel Zaldivar', Chen Ch Hong ${ }^{4}$, \\ Monica Viviana Alvarado-Mora ${ }^{5}$, Rebecca Smith', Alma Y Ortiz', \\ João Renato Rebello Pinho ${ }^{5}$, Juan Cristina ${ }^{6}$, Juan Miguel Pascale ${ }^{1,7 /+}$
}

\begin{abstract}
${ }^{1}$ Gorgas Memorial Institute for Health Studies, Panama, Panama ${ }^{2}$ Department of Biotechnology, Acharya Nagarjuna University, Guntur, India ${ }^{3}$ Instituto de Investigaciones Científicas y Servicios de Alta Tecnología-AIP, Ciudad del Saber, Clayton, Panama

${ }^{4}$ Internal Medicine, Massachusetts General Hospital, Boston, MA, USA ${ }^{5}$ Laboratório de Gastroenterologia e Hepatologia Tropical,

Departamento de Gastroenterologia, Instituto de Medicina Tropical, Faculdade de Medicina, Universidade de São Paulo,

São Paulo, SP, Brasil ' ${ }^{2}$ aboratorio de Virología Molecular, Centro de Investigaciones Nucleares, Facultad de Ciencias,

Universidad de la República, Montevideo, Uruguay ${ }^{7}$ School of Medicine, University of Panama, Panama, Panama
\end{abstract}

Despite the effectiveness of current hepatitis $B$ virus (HBV) vaccines, it is estimated that 350 million individuals suffer from chronic HBV infection and more than $50 \%$ of these affected individuals live on the Asian continent. Panama is a country with a great diversity of foreign groups; the Chinese community is a large example of this phenomenon. There is an urgent need to perform studies that evaluate the prevalence and the genetic diversity of $H B V$ in this community. This study aimed to evaluate the prevalence of HBV and its genotypes and mutant variants in the Chinese population residing in Panama. In total, 320 subjects were enrolled in the study. Forty-two subjects (13.1\%) were positive for $\mathrm{HBs} A g$ and $\mathrm{HBV}$-DNA from 18 subjects revealed the presence of genotypes B2 and C1. Secondary mutations associated with drug resistance at positions rtV207L and rtN239T of the reverse transcriptase gene were identified. Additionally, the mutation pair A1762T/G1764A was found in three samples and the mutation G1896A was detected in an HBeAg-negative subject. In conclusion, to our knowledge, this is the first study to report high HBV prevalence rates in resident ethnic Chinese in Central America and the presence of genotypes B2 and C1 in this region.

Key words: hepatitis B - Panama - Bayesian analysis - genotype C1 - genotype B2

There are approximately 350 million individuals chronically infected with hepatitis B virus (HBV); more than $50 \%$ of these individuals live in Asian countries. HBV is classified into different genotypes based on $8 \%$ divergence over the complete genome or $4 \%$ divergence in the S gene (Okamoto et al. 1988, Kidd-Ljunggren et al. 2002, Kurbanov et al. 2010). According to this definition, 10 genotypes, A-I (Orito et al. 1989, Naumann et al. 1993, Blitz \& Pujol 1998, Stuyver \& Gendt 2000, ArauzRuiz \& Norder 2002, Olinger et al. 2008, Yu et al. 2010), have been reported.

HBV genotypes have a variable geographical distribution: genotype $\mathrm{A}$ is the predominant genotype in $\mathrm{Eu}-$ rope, India, Africa and North America, genotypes B and $\mathrm{C}$ are more prevalent in China, Japan and Southeast Asia, genotype D is found around the Mediterranean area, in the Middle-East and in Latin America (Kramvis et al. 2005), genotype $\mathrm{E}$ is found in West Africa and in the Af-

doi: 10.1590/0074-0276108052013002

Financial support: SENACYT-PANAMA (FID09-050)

AAM was supported by a fellowship from SENACYT-IFARHU.

+ Corresponding author: jpascale@gorgas.gob.pa

Received 23 January 2013

Accepted 26 April 2013
ro-Colombian population (Odemuyiwa et al. 2001, Alvarado Mora et al. 2010), genotype $\mathrm{F}$ is found in Central and South America (Pineiro y Leone et al. 2003, Torres et al. 2011), genotype $G$ is found in France, Mexico and the United States of America (Stuyver \& Gendt 2000), genotype $\mathrm{H}$ is found in Mexico (Torres et al. 2011) and Central America (Arauz-Ruiz \& Norder 2002), genotype I is found in Vietnam and Laos (Olinger et al. 2008, Tran et al. 2008) and genotype J was recently found in a Japanese patient with hepatocellular carcinoma (HCC) (Tatematsu et al. 2009). Due to the world-wide distribution pattern of HBV genotypes, we can trace the spread of HBV infection in immigrants and within regions in a country (Campos et al. 2005). This also allows us to consider the possible frequency of recombination between genotypes within a region (Bowyer SM \& Sim 2000, Khan et al. 2008, Shi et al. 2013) and to attempt to correlate genotypes with different clinical outcomes. Studies suggest that genotypes B-D are related to poor clinical outcomes (Echevarria \& Avellon 2006).

Another factor affecting the prognosis in HBV infection is the presence of mutations in the $\mathrm{C}$ and $\mathrm{D}$ domains of the HBV reverse transcriptase (HBV-RT) gene, which produce changes in the primary structure of the HBV-RT and give rise to resistance to antiretroviral drugs (Michailidis et al. 2012). Mutations in the Enh II, pre-core $(\mathrm{PC})$ and basal core promoter $(\mathrm{BCP})$ regions of HBV may also cause changes in the binding of transcription factors in the BCP (Yin et al. 2011), affecting tran- 
scription of the PC mRNA and pre-genomic RNA and decreasing or even abolishing the secretion of $\mathrm{HBeAg}$ and enhancing viral replication rates, with subsequent hepatic damage (Buckwold et al. 1996).

Despite HBV vaccination policies around the world, there is still a high prevalence of chronic HBV (CHB) infection, especially among Asian populations (Merrill \& Hunter 2011). Panama is a country with a high diversity of growing foreign communities; the Chinese population is a large example (INEC 2011). In the metropolitan areas of several developed cities (Lavanchy 2004, Pollack et al. 2006, Bini \& Perumalswami 2010, Kallman et al. 2011), there is growing evidence of a high prevalence of HBV in Asian populations, but little is known regarding the molecular characteristics of the virus in these populations. To successfully implement a universal HBV vaccination program in Central American countries, it will be necessary to study the prevalence and molecular characteristics of the HBV genotypes that infect the risk groups in the region. The purpose of this study was to evaluate the prevalence of HBV infection and to describe the HBV genotypes and mutations in the resident Chinese population in Panama City.

\section{PATIENTS, MATERIALS AND METHODS}

Sample collection - The Institutional Review Board of the Gorgas Memorial Institute for Health Studies approved this study. All of the participants signed an informed consent form before inclusion in the study. This research was a cross-sectional study performed during 2003. Approximately 500 subjects of Chinese descent based on last name were randomly selected and contacted using the phone directory for the Chinese communities in the metropolitan area of Panama City. The subjects who answered the call were included in the study based on the completion of a consent form and their willingness to provide a blood sample at a designated sample collection site. The questionnaire was filled out with the assistance of a translator and blood samples were collected by venipuncture. Plasma was separated from the blood cells by centrifugation for $10 \mathrm{~min}$ at $2,500 \mathrm{rpm}$ and was stored at $-80^{\circ} \mathrm{C}$ until testing. The samples were evaluated for hepatitis B surface antigen [(HBsAg), AxSYM HBsAg (V2)] and hepatitis E antigen [(HBe) AxSYM HBe 2.0] according to the manufacturer's instructions.

Partial PreS gene amplification - DNA was extracted and amplified from the samples that were positive for HBsAg to detect and quantify the amount of HBV-DNA that was present using real-time polymerase chain reaction (PCR) according to previously described methods (Liu et al. 2007). Those samples with detectable viraemia were subjected to a nested PCR that yielded a 1,058-bp fragment that simultaneously covered amino acids 35-226 of the small surface gene and amino acids 42-280 of the HBV-RT gene, which corresponded to RT domains A-E. The following primers were used: HBV66 and HBV1121 for the first-round PCR and HBV095 (Takahashi et al. 2004b) and HBV1121 (Gunther et al. 1998) for the second-round PCR. The PCR conditions were similar in both reactions: $94^{\circ} \mathrm{C}$ for $6 \mathrm{~min}, 40$ cycles of $94^{\circ} \mathrm{C}$ for $30 \mathrm{sec}, 55^{\circ} \mathrm{C}$ for $30 \mathrm{sec}$ and $72^{\circ} \mathrm{C}$ for $1 \mathrm{~min}$ and a final extension for $7 \mathrm{~min}$ at $72^{\circ} \mathrm{C}$.

The 1,058-bp product was sequenced using the following primers: HBV477, HB1842 (Takahashi et al. 2004b), HB066, HBV676 and HBV1121. The sequencing reaction was performed using Big Dye Terminator v.3.1 in an ABI 3130xl automatic DNA sequencer with an initial denaturation at $96^{\circ} \mathrm{C}$ followed by 30 cycles of $96^{\circ} \mathrm{C}$ for $10 \mathrm{sec}, 50^{\circ} \mathrm{C}$ for $5 \mathrm{sec}$ and $60^{\circ} \mathrm{C}$ for $4 \mathrm{~min}$. The sequences obtained were inspected visually for quality and contigs were created using Sequencher v.4.5 software and submitted to GenBank with the accessions JX507200-JX507215 and JX86998-JX870001.

Full-length genome amplification - Samples that were positive for the short region $(1,058 \mathrm{bp})$ were chosen for genome amplification. Primers P1 and P2 (Gunther et al. 1998) were used to amplify an approximately 3,220-bp region using Platinum ${ }^{\circledR}$ PCR Super Mix High Fidelity enzymes (Invitrogen) with the following PCR conditions: initial denaturation at $96^{\circ} \mathrm{C}$ for $15 \mathrm{~min}, 40$ cycles of $94^{\circ} \mathrm{C}$ for $30 \mathrm{sec}, 50^{\circ} \mathrm{C}$ for $90 \mathrm{sec}$ and $68^{\circ} \mathrm{C}$ for $2 \mathrm{~min}$, with increments of $90 \mathrm{sec}$ every 10 cycles and a final extension step of $10 \mathrm{~min}$ at $68^{\circ} \mathrm{C}$. DNA bands were visualised on a $1 \%$ agarose gel. The circular PCR amplicon obtained was sequenced directly as previously reported ( $\mathrm{Li}$ et al. 2010).

Phylogenetic analysis - The partial HBV genome sequences obtained in this study were genotyped using phylogenetic reconstructions and reference sequences for each HBV genotype obtained from GenBank ( $\mathrm{n}=$ 138) (data available upon request). These sequences were aligned using Muscle software (Edgar 2004) and edited in SE-AL software (tree.bio.ed.ac.uk/software/seal/). For the phylogenetic analysis, the missing nucleotides were coded as "missing characters" in the nexus block. Bayesian phylogenetic analyses were performed through Markov Chain Monte Carlo (MCMC) simulations implemented in BEAST v.1.5.3 (Drummond et al. 2007). Ten million generations were sufficient to obtain convergence of the parameters. MCMC simulations were performed to obtain the best possible estimates under both relaxed uncorrelated $\log _{\text {normal }}$ and exponential molecular clock conditions and when using the model of nucleotide substitution $(\mathrm{GTR}+\mathrm{G}+\mathrm{I})$. The molecular clock that best fitted the data was chosen by Bayes factor comparison. The maximum clade credibility tree was obtained from summarising the 10,000 substitution trees and $10 \%$ of the burn-in was then removed using Tree Annotator v.1.5.3 (Drummond et al. 2007).

Mutation analysis - For the detection and analysis of mutations in the Enh II, PC and BCP regions, the nucleotide sequences were aligned with the reference sequence for genotype C X04615 using Muscle (Edgar 2004). For the analysis of the substitutions in the polymerase and small surface gene nucleotides, the sequences were translated and compared using MacClade v.4.08. The HBV-RT sequences were evaluated for the presence of residues previously reported as being involved in drug resistance (Michailidis et al. 2012). The major hydro- 
philic region (MHR) of the small surface protein was evaluated for the presence of escape mutations (Coleman et al. 1999, Ma \& Wang 2012).

\section{RESULTS}

Demographic and serological results - In total, 500 subjects answered the initial phone call and 180 individuals were excluded because they either did not sign the informed consent form or did not agree to give a blood sample for the study. A total of 320 samples were collected and included in the study: 135 men $(42.2 \%)$ and 185 women (57.8\%) with a mean age of 33 years old $(95 \%$ confidence interval: 31.4-34.9 years old). The youngest participant was seven years old; the oldest participant was 79 years old. The birthplace for the majority of the participants was China (172, 53.8\%); however, 115 participants (35.9\%) were born in Panama (Table).

Forty-two participants (13.1\%) were HBsAg-positive; of these, 10 subjects $(23.8 \%)$ were also HBeAg-positive. Most of the positive subjects $(n=27)$ were in the age group of $19-45$ years old, representing $64 \%$ of the study population. With respect to birthplace, 25 of the HBsAgpositive subjects (59.5\%) were born in China, 12 (28.5\%) in Panama and $5(11.9 \%)$ did not answer the question.

Molecular biology results - DNA was extracted from all of the HBsAg-positive samples $(n=42)$ and the amount of HBV-DNA was quantified using real-time PCR. Eighteen samples had undetectable viral loads $(<50$ copies/ $\mathrm{mL}$ ) and 24 were positive for HBV-DNA. The HBV-DNA from 18 of the 22 samples with higher copy numbers was sequenced. Phylogenetic analysis revealed that 11 samples (61.1\%) were located in the genotype B2 cluster and that seven samples (38.9\%) were located in the genotype $\mathrm{C} 1$ cluster (Fig. 1). Of the 24 positive subjects, 12 were born in China (6 B2, $6 \mathrm{Cl}$ ), five were born in Panama (3 B2, $2 \mathrm{C1}$ ) and one did not answer the question (Fig. 2A). There was clustering among the Chinese-Panamanian samples, indicating possible common origins.

Considering the divergence found in this group of samples, evaluation of the mutations was performed to characterise other molecular risk factors such as resis- tance to HBV-RT inhibitors and changes in several important regions, including the MHR of the surface antigen. Whole-genome amplification was performed on 10 samples to evaluate the $\mathrm{PC}$ and $\mathrm{BCP}$ regions and to explore the possible existence of recombinant strains.

No primary mutations associated with resistance to nucleos(t)ide HBV-RT inhibitors were identified upon analysis of the HBV polymerase gene. Two secondary mutations that were potentially associated with resistance, $\mathrm{rtV} 207 \mathrm{~L}$ and $\mathrm{rtN} 238 \mathrm{~T}$, were identified in one $(6 \%)$ and five $(33 \%)$ of the analysed samples, respectively (Fig. 2A).

The analysis of the MHR mutations revealed a change in residue Q129H in two samples (11\%). This change has been reported to affect the reactivity of at least one diagnostic assay. No other mutations related to escape from detection in HBsAg immunoassays, immunisation or hepatitis B immune globulin (HBIG) treatment were detected.

The analysis of mutations in the Enh II, PC and $\mathrm{BCP}$ regions of the 10 samples revealed the following results: the mutation G1613A was identified in two samples (20\%), two samples (20\%) had the mutation pair A1762T/G1764A and one sample carried both G1896A and the A1762T/G1764A double mutation. The patient from whom this sample was obtained had an $\mathrm{HBeAg}$ negative phenotype (Fig. 2B).

Analysis to detect recombination among the samples using the RDP4 software gave no evidence of recombination.

\section{DISCUSSION}

The Republic of Panama had approximately 3,405,813 inhabitants in 2010 (INEC 2011), with approximately half of the population living in the capital city. The population of Chinese residents in Panama is estimated at 102,000 individuals, representing $2.9-3.1 \%$ of the total population. In this study, we found a high prevalence of HBV in the Chinese community in Panama City, approximately $13.1 \%$, which is comparable to the prevalence in high endemic areas of China (Zeng et al. 2005) and is 20 times higher than the observed prevalence in female sex workers in Panama (Hakre et al. 2012). A similar

TABLE

Demographic, HBsAg, HBeAg and genotype data collected in 2003 for Panamanians of Chinese origin

\begin{tabular}{|c|c|c|c|c|c|c|c|c|c|c|c|c|c|}
\hline \multirow[b]{3}{*}{ Age range } & \multicolumn{2}{|c|}{ Gender } & & & & & & & \multicolumn{4}{|c|}{ Place of birth } & \multirow{3}{*}{$\begin{array}{l}\text { Total } \\
\text { n (\%) }\end{array}$} \\
\hline & Male & Female & \multicolumn{6}{|c|}{ Age range } & Panama & China & Other & Unknown & \\
\hline & $\mathrm{n}(\%)$ & $\mathrm{n}(\%)$ & $0-10$ & $11-18$ & $19-30$ & $31-45$ & $46-60$ & $>61$ & n (\%) & $\mathrm{n}(\%)$ & n (\%) & $\mathrm{n}(\%)$ & \\
\hline HBsAg positive & $19(5.9)$ & $23(7.2)$ & 2 & 5 & 13 & 14 & 7 & 1 & $12(3.8)$ & $25(7.8)$ & $0(0)$ & $5(1.6)$ & $42(13.1)$ \\
\hline $\mathrm{HBeAg}+$ & $5(1.6)$ & $5(1.6)$ & 0 & 3 & 5 & 1 & 1 & 0 & $4(1.3)$ & $6(1.9)$ & $0(0)$ & $0(0)$ & $10(3.1)$ \\
\hline HBeAg- & $14(4.4)$ & $18(5.6)$ & 2 & 2 & 8 & 13 & 6 & 1 & $8(2.5)$ & $19(5.9)$ & $0(0)$ & $5(1.6)$ & $32(10)$ \\
\hline HBsAg negative & 116 & $162(50.6)$ & 20 & 30 & 86 & 71 & 57 & 14 & $103(32.2)$ & $147(45.9)$ & $6(1.9)$ & $22(6.9)$ & $278(86.9)$ \\
\hline Total & $135(42.2)$ & $185(57.8)$ & 22 & 35 & 99 & 85 & 64 & 15 & 115 (35.9) & $172(53.8)$ & $6(1.9)$ & $27(8.4)$ & 320 \\
\hline
\end{tabular}


phenomenon has been observed in other cosmopolitan areas around the world (Merican et al. 2000, Pollack et al. 2006, Khan et al. 2008).

Sixty-four percent of the study participants who were HBsAg-positive were between 19-45 years old, indicating active infection in adults. In Panama, an HBV vaccine is currently available for free for children and health workers. However, adults in high-risk groups, such as the Chinese community, are not included in national vaccination programs.

The spread of infectious diseases across the world occurs mainly as a consequence of human migration, which is likely the case for HBV infection in the Chinese population in Panama because a high number of the HBsAgpositive subjects $(25,59.5 \%)$ were born in China. This situation has epidemiological importance because the monitoring of HBsAg seroprevalence among this population will help to reduce the incidence and prevalence of HBV cases in regions like Panama that have high levels of immigration from a diverse array of countries.

This study showed evidence that the HBV genotypes detected in the Chinese population of Panama are similar to the genotypes found in Asian countries. Phylogenetic analysis placed the Panamanian samples within clades of genotypes B2 $(n=11,61.1 \%)$ and $\mathrm{Cl}(\mathrm{n}=7,38.9 \%)$. To our knowledge, until now, these two genotypes have not been described in Central America. However, in South America, there have been reports of the transmission of genotypes B and C between Japanese immigrant and native Bolivian populations (Khan et al. 2008).

Studies of hepatitis B genotypes are useful for tracing migration patterns within distinct communities. This fact has been especially notable among the Chinese populations settled around the world (Merican et al. 2000, Pollack et al. 2006). Finding both genotypes B and $\mathrm{C}$ in this population has important epidemiological implications. The circulation of several genotypes in a small territory, as is the case in Panama City, increases the possibility of identifying subjects that are co-infected with more than one genotype; this situation increases the likelihood of recombination among the genotypes (Alvarado-Mora et al. 2010).

The frequency of different HBV genotypes in a specific region and the fact that $\mathrm{HBV}$ has a higher evolution

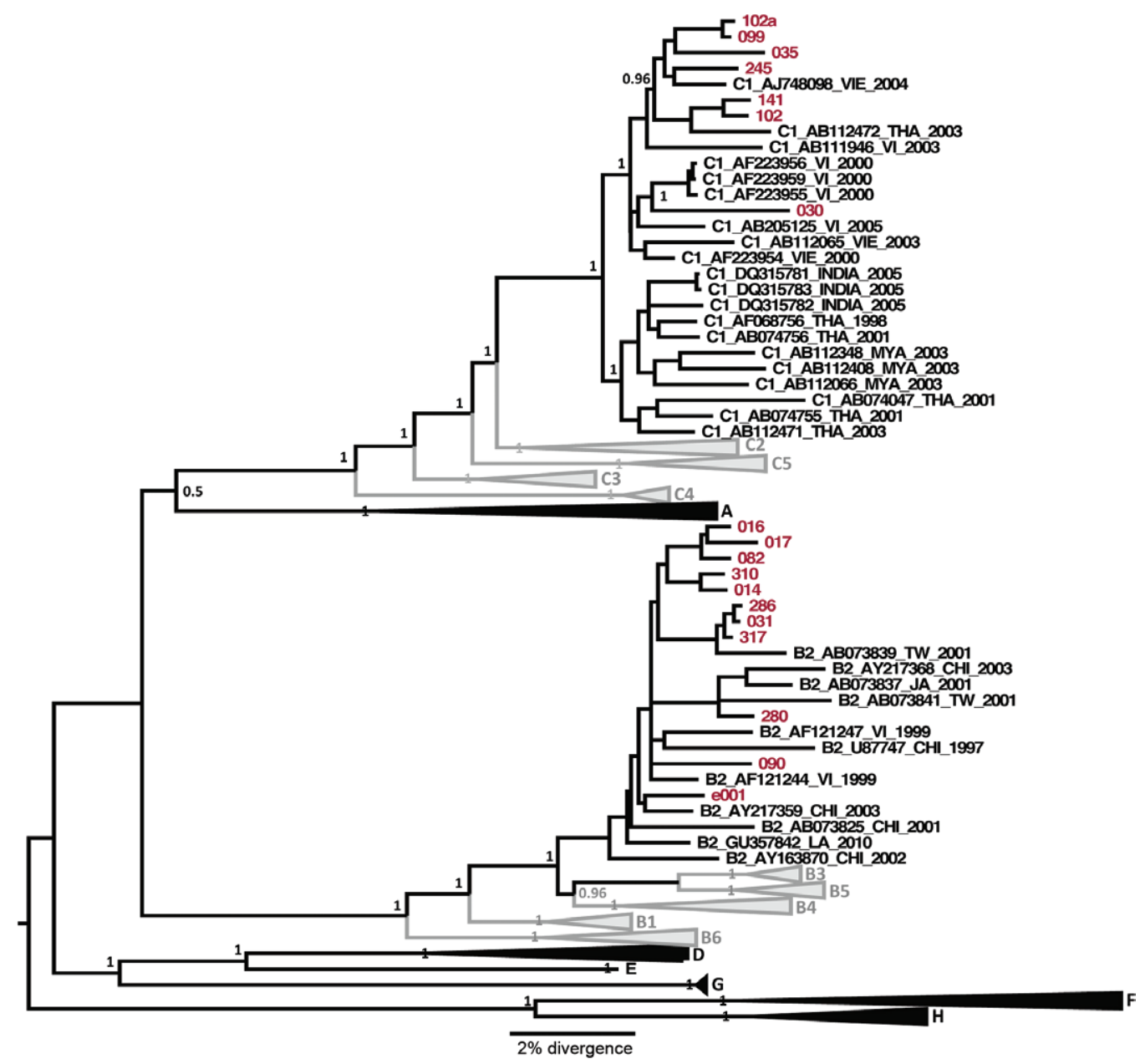

Fig. 1: the maximum clade credibility tree was estimated by Bayesian analysis of 138 hepatitis B virus (HBV) sequences. The posterior probabilities of the key nodes are depicted above the respective nodes. Samples obtained from Panama $(n=17$, red taxa) were analysed together with other worldwide strains. The clusters of other HBV genotypes were collapsed. 
rate compared with other DNA viruses (Fares \& Holmes 2002, Pineiro y Leone et al. 2003, Takahashi et al. 2004a) increase the possibilities of both recombination among the genotypes (Andernach et al. 2012, Shi et al. 2012, Zhou et al. 2012) and the development of greater variability, which has occurred in genotype I (Yu et al. 2010). Recombination analysis of 10 samples from this study did not show enough evidence for recombination in Panama, likely as a result of cultural and insular tendencies among Panamanian Chinese and immigrant communities in general.

In addition to the genotyping portion of this study, we implemented a PCR method that allows amplification of a region from amino acids 35-226 of the small surface gene and amino acids 42-280 of HBV-RT, which covers the A-E RT domains. This fragment was used to evaluate residue changes that cause antiretroviral drug resistance and allow escape from detection in HBsAg immunoassays, immunisation or HBIG treatment. Although primary drug resistance changes in the RT domains studied were completely absent, secondary drug resistance changes in domains C (rtV207L) and D (rtN238T) were identified in one $(6 \%)$ and five $(31 \%)$ samples, respectively, which were higher than previous reports, although the study group was small $(n=16)$ (Zhong et al. 2012). However, we cannot discount the importance of these mutations when considering treatments for naïve populations.

With regard to the MHR region, in almost all of the samples, no residues were found with substitutions related to escape from detection in HBsAg immunoassays, immunisation or HBIG treatment. The substitution Q129H was observed in one sample; this residue has been reported as capable of reducing serological detection in some diagnostic assays (Coleman et al. 1999, Ma \& Wang 2012).

Mutation analysis in the Enh II region found the G1613A mutation in two subjects; although both samples were $\mathrm{HBeAg}$-positive, in vitro studies have linked this mutation with $\mathrm{HBeAg}$ suppression in CHB (Li et al. 2011).

In three samples, mutations were identified in the $\mathrm{PC}$ and $\mathrm{BCP}$ regions that are associated with either the suppression of $\mathrm{HBeAg}$ secretion and the development of liver cirrhosis or HCC. Mutations in the PC region affect the secretion of HBeAg (Tong et al. 2007, Tangkijvanich

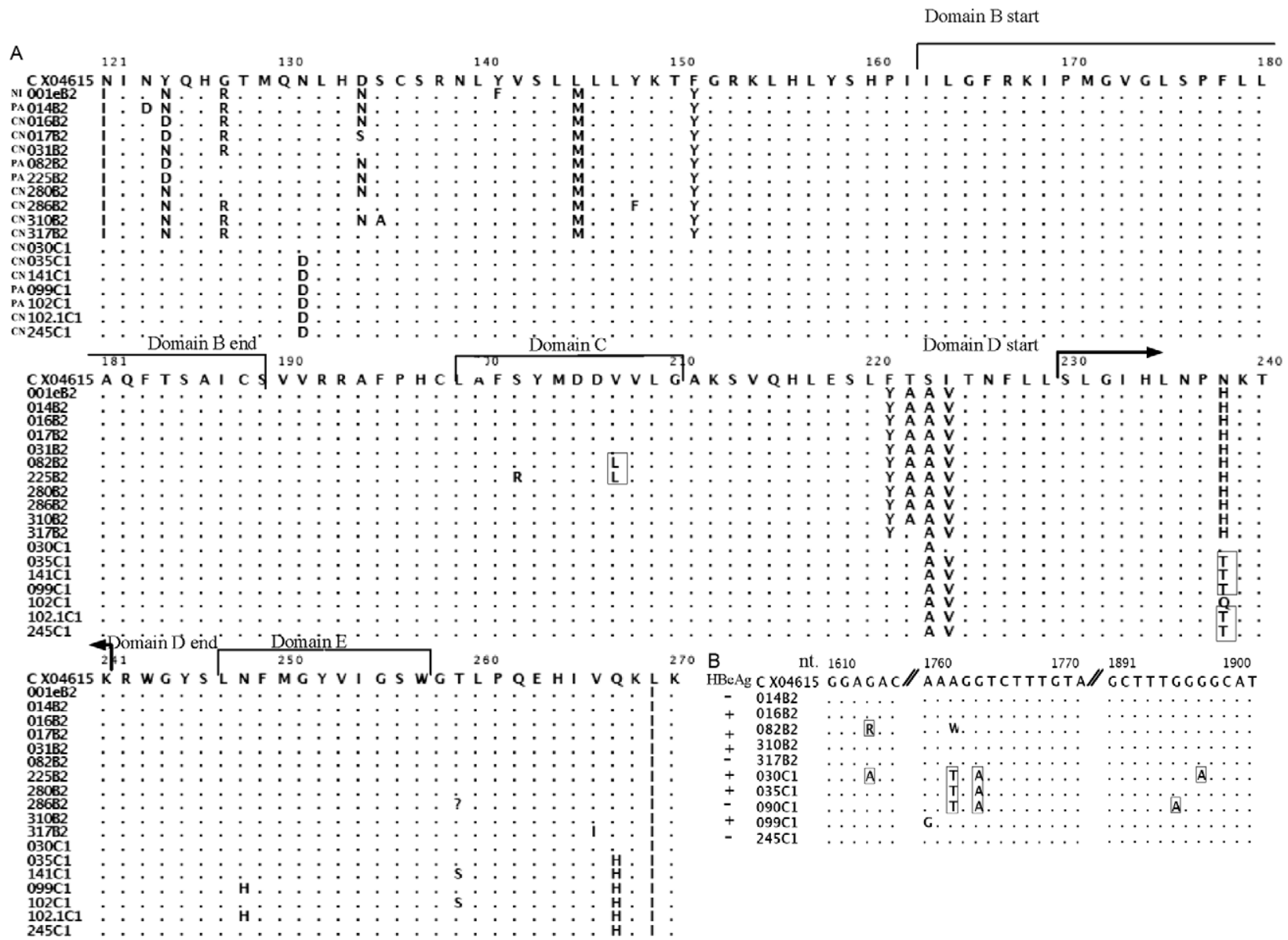

Fig. 2A: amino acid alignments of hepatitis B virus reverse transcriptase (HBV-RT) gene isolated in this study from HBsAg positive subject naïve to treatment $(n=18)$. Four domains of RT protein are shown. Dots represent the same residue as in reference sequence. Substitutions of relevance are in box. Place of birth of the subjects is indicated (CN: China; NI: no information; PA: Panama); B: nucleotide alignments of the HBV, EnhII, precore and basal core promoter regions isolated in this study from HBsAg positive $(n=10)$. Dots represent the same nucleotide as in reference sequence. Mutations of relevance are in box. HBeAg status is shown. 
et al. 2010) because this region controls the transcription of PC mRNA and pre-genomic RNA (Buckwold et al. 1996). The mutation pair A1762T/G1764A was found in three samples, with one sample concurrently showing the BCP mutation G1896A; this group of mutations abolished the secretion of $\mathrm{HBeAg}$ in this specimen, as evidenced by a negative result in the immunoassay used.

Collectively, these mutations are molecular indicators that patients may develop serious chronic illness, which could be a major public health problem in Panama that would not necessarily be restricted to the Chinese population.

Studies that determine the seroprevalence, genotype and mutation profile of HBV are useful from a public health point of view for identifying risk factors for the spread of different HBV genotypes and in applying epidemiological measures with the aim of decreasing the prevalence of HBV in particular risk groups. These measures are important in reducing the rate of evolution of HBV and in maintaining the efficacy of current vaccines.

In conclusion, to our knowledge, this is the first study that reports high HBV prevalence rates in resident ethnic Chinese in Central America and the presence of genotypes $\mathrm{B} 2$ and $\mathrm{C} 1$ in this region.

Further studies designed to evaluate the potential presence of the mutations found in Chinese populations in other countries from Central America are needed to achieve a better understanding of the regional impact of HBV infection.

\section{ACKNOWLEDGEMENTS}

To the Chinese-Panamanian Association, for their support with the study and help in translating the survey.

\section{REFERENCES}

Alvarado-Mora MV, Romano CM, Gomes-Gouvea MS, Gutierrez MF, Carrilho FJ, Pinho JR 2010. Molecular epidemiology and genetic diversity of hepatitis $\mathrm{B}$ virus genotype $\mathrm{E}$ in an isolated Afro-Colombian community. J Gen Virol 91: 501-508.

Andernach IE, Jutavijittum P, Samountry B, Yousukh A, Thammavong T, Hubschen JM, Muller CP 2012. A high variability of mixed infections and recent recombinations of hepatitis B virus in Laos. PLoS ONE 7: e30245.

Arauz-Ruiz P, Norder H 2002. Genotype H: a new Amerindian genotype of hepatitis B virus revealed in Central America. J Gen Virol 83: 2059-2073.

Bini EJ, Perumalswami PV 2010. Hepatitis B virus infection among American patients with chronic hepatitis $\mathrm{C}$ virus infection: prevalence, racial/ethnic differences and viral interactions. Hepatology 51: 759-766.

Blitz L, Pujol F 1998. Antigenic diversity of hepatitis B virus strains of genotype $\mathrm{F}$ in Amerindians and other population groups from Venezuela. J Clin Microbiol 36: 648-651.

Bowyer SM, Sim JG 2000. Relationships within and between genotypes of hepatitis B virus at points across the genome: footprints of recombination in certain isolates. J Gen Virol 81: 379-392.

Buckwold VE, Xu Z, Chen M, Yen TS, Ou JH 1996. Effects of a naturally occurring mutation in the hepatitis $\mathrm{B}$ virus basal core promoter on precore gene expression and viral replication. $J$ Virol 70: $5845-5851$
Campos RH, Mbayed VA, Pineiro YLFG 2005. Molecular epidemiology of hepatitis B virus in Latin America. J Clin Virol 34 (Suppl. 2): S8-S13.

Coleman PF, Chen YC, Mushahwar IK 1999. Immunoassay detection of hepatitis B surface antigen mutants. J Med Virol 59: 19-24.

Drummond AJ, Rambaut A 2007. BEAST: Bayesian evolutionary analysis by sampling trees. BMC Evol Biol 7: 214 .

Echevarria JM, Avellon A 2006. Hepatitis B virus genetic diversity. J Med Virol 78 (Suppl. 1): S36-S42.

Edgar RC 2004. MUSCLE: a multiple sequence alignment method with reduced time and space complexity. BMC Bioinformatics 5: 113.

Fares MA, Holmes EC 2002. A revised evolutionary history of hepatitis B virus (HBV). J Mol Evol 54: 807-814.

Gunther S, Sommer G, Von Breunig F, Iwanska A, Kalinina T, Sterneck M, Will H 1998. Amplification of full-length hepatitis B virus genomes from samples from patients with low levels of viremia: frequency and functional consequences of PCR-introduced mutations. J Clin Microbiol 36: 531-538.

Hakre S, Arteaga G, Nunez AE, Bautista CT, Bolen A, Villarroel M, Peel SA, Paz-Bailey G, Scott PT, Pascale JM 2012. Prevalence of HIV and other sexually transmitted infections and factors associated with syphilis among female sex workers in Panama. Sex Transm Infect 89: 156-164.

INEC - Instituto Nacional de Estadística y Censo Panama 2011. Censos Nacionales 2010. Available from: estadisticas.contraloria. gob.pa/Resultados2010/tabulados/Excel/Cuadro12.xls.

Kallman JB, Tran S, Arsalla A, Haddad D, Stepanova M, Fang Y, Wrobel VJ, Srishord M, Younossi ZM 2011. Vietnamese community screening for hepatitis B virus and hepatitis $\mathrm{C}$ virus. $J$ Viral Hepat 18: 70-76.

Khan A, Tanaka Y, Saito H, Ebinuma H, Sekiguchi H, Iwama H, Wakabayashi G, Kamiya T, Kurbanov F, Elkady A, Mizokami M 2008. Transmission of hepatitis B virus (HBV) genotypes among Japanese immigrants and natives in Bolivia. Virus Res 132: 174-180.

Kidd-Ljunggren K, Miyakawa Y, Kidd AH 2002. Genetic variability in hepatitis B viruses. J Gen Virol 83: 1267-1280.

Kramvis A, Kew M, Francois G 2005. Hepatitis B virus genotypes. Vaccine 23: 2409-2423.

Kurbanov F, Tanaka Y, Mizokami M 2010. Geographical and genetic diversity of the human hepatitis B virus. Hepatol Res 40: 14-30.

Lavanchy D 2004. Hepatitis B virus epidemiology, disease burden, treatment and current and emerging prevention and control measures. J Viral Hepat 11: 97-107.

Li MS, Lau TC, Chan SK, Wong CH, Ng PK, Sung JJ, Chan HL, Tsui SK 2011. The G1613A mutation in the HBV genome affects $\mathrm{HBeAg}$ expression and viral replication through altered core promoter activity. PLoS ONE 6: e21856.

Li Y, Zhu M, Guo Y, Chen W, Li G 2010. Full-length hepatitis B virus sequences from naïve patients with fluctuation of viral load during ADV monotherapy. Virus Genes 40: 155-162.

Liu Y, Hussain M, Wong S, Fung SK, Yim HJ, Lok ASF 2007. A genotype-independent real-time PCR assay for quantification of hepatitis B virus DNA. J Clin Microbiol 45: 553-558.

Ma Q, Wang Y 2012. Comprehensive analysis of the prevalence of hepatitis B virus escape mutations in the major hydrophilic region of surface antigen. J Med Virol 84: 198-206.

Merican I, Guan R, Amarapuka D, Alexander MJ, Chutaputti A, Chien RN, Hasnian SS, Leung N, Lesmana L, Phiet PH, Sjalfoellah Noer 
HM, Sollano J, Sun HS, Xu DZ 2000. Chronic hepatitis B virus infection in Asian countries. J Gastroenterol Hepatol 15: 1356-1361.

Merrill RM, Hunter BD 2011. Seroprevalence of markers for hepatitis B viral infection. Int J Infect Dis 15: e78-e121.

Michailidis E, Kirby KA, Hachiya A, Yoo W, Hong SP, Kim SO, Folk WR, Sarafianos SG 2012. Antiviral therapies: focus on hepatitis B reverse transcriptase. Int J Biochem Cell Biol 44: 1060-1071.

Naumann H, Schaefer S, Yoshida CF, Gaspar AM, Repp R, Gerlich WH 1993. Identification of a new hepatitis B virus (HBV) genotype from Brazil that expresses HBV surface antigen subtype adw4. J Gen Virol 74: 1627-1632.

Odemuyiwa SO, Mulders MN, Oyedele OI, Ola SO, Odaibo GN, Olaleye DO, Muller CP 2001. Phylogenetic analysis of new hepatitis $\mathrm{B}$ virus isolates from Nigeria supports endemicity of genotype $\mathrm{E}$ in West Africa. J Med Virol 65: 463-469.

Okamoto H, Tsuda F, Sakugawa H, Sastrosoewignjo RI, Imai M, Miyakawa Y, Mayumi M 1988. Typing hepatitis B virus by homology in nucleotide sequence: comparison of surface antigen subtypes. J Gen Virol 69: 2575-2583.

Olinger CM, Jutavijittum P, Hubschen JM, Yousukh A, Samountry B, Thammavong T, Toriyama K, Muller CP 2008. Possible new hepatitis B virus genotype, Southeast Asia. Emerg Infect Dis 14: 1777-1780.

Orito E, Mizokami M, Ina Y, Moriyama EN, Kameshima N, Yamamoto M, Gojobori T 1989. Host-independent evolution and a genetic classification of the hepadnavirus family based on nucleotide sequences. Proc Natl Acad Sci 86: 7059-7062.

INEC - Instituto Nacional de Estadística y Censo Panama 2011. Censos Nacionales 2010. Available from: estadisticas.contraloria. gob.pa/Resultados2010/tabulados/Excel/Cuadro12.xls.

Pineiro y Leone FG, Mbayed VA, Campos RH 2003. Evolutionary history of hepatitis B virus genotype F: an in-depth analysis of Argentine isolates. Virus Genes 27: 103-110.

Pollack H, Wan K, Ramos R, Rey M, Sherman A, Tobias H, Tsang T, Tso A, Charles B, Korenblit P, Son S, Poon E, Bialek S, Bell B 2006. Screening for chronic hepatitis B among Asian/Pacific Islander populations New York City, 2005. Morb Mortal Wkly Rep 55: 505-509.

Shi W, Carr MJ, Dunford L, Zhu C, Hall WW, Higgins DG 2012. Identification of novel inter-genotypic recombinants of human hepatitis B viruses by large-scale phylogenetic analysis. Virology 427: $51-59$

Shi W, Zhang Z, Ling C, Zheng W, Zhu C, Carr MJ, Higgins DG 2013. Hepatitis B virus subgenotyping: history, effects of recombination, misclassifications and corrections. Infect Genet Evol 16C: 355-361.

Stuyver L, Gendt S 2000. A new genotype of hepatitis B virus: complete genome and phylogenetic relatedness. J Gen Virol 81: 67-74.
Takahashi K, Toyota J, Karino Y, Kang JH, Maekubo H, Abe N, Mishiro S 2004a. Estimation of the mutation rate of hepatitis E virus based on a set of closely related 7.5-year-apart isolates from Sapporo, Japan. Hepatol Res 29: 212-215.

Takahashi M, Nishizawa T, Gotanda Y, Tsuda F, Komatsu F, Kawabata T, Hasegawa K, Altankhuu M, Chimedregzen U, Narantuya L, Hoshino H, Hino K, Kagawa Y, Okamoto H 2004b. High prevalence of antibodies to hepatitis $\mathrm{A}$ and $\mathrm{E}$ viruses and viremia of hepatitis B, C, and D viruses among apparently healthy populations in Mongolia. Clin Diagn Lab Immunol 11: 392-398.

Tangkijvanich P, Sa-Nguanmoo P, Mahachai V, Theamboonlers A, Poovorawan Y 2010. A case-control study on sequence variations in the enhancer II/core promoter/precore and $\mathrm{X}$ genes of hepatitis $\mathrm{B}$ virus in patients with hepatocellular carcinoma. Hepatol Int 4: $577-584$

Tatematsu K, Tanaka Y, Kurbanov F, Sugauchi F, Mano S, Maeshiro T, Nakayoshi T, Wakuta M, Miyakawa Y, Mizokami M 2009. A genetic variant of hepatitis B virus divergent from known human and ape genotypes isolated from a Japanese patient and provisionally assigned to new genotype J. J Virol 83: 10538-10547.

Tong MJ, Blatt LM, Kao JH, Cheng JT, Corey WG 2007. Basal core promoter T1762/A1764 and precore A1896 gene mutations in hepatitis B surface antigen-positive hepatocellular carcinoma: a comparison with chronic carriers. Liver Int 27: 1356-1363.

Torres C, Pineiro y Leone FG, Pezzano SC, Mbayed VA, Campos RH 2011. New perspectives on the evolutionary history of hepatitis B virus genotype F. Mol Phylogenet Evol 59: 114-122.

Tran TT, Trinh TN, Abe K 2008. New complex recombinant genotype of hepatitis B virus identified in Vietnam. J Virol 82: 5657-5663.

Yin J, Xie J, Liu S, Zhang H, Han L, Lu W, Shen Q, Xu G, Dong H, Shen J, Zhang J, Han J, Wang L, Liu Y, Wang F, Zhao J, Zhang Q, Ni W, Wang H, Cao G 2011. Association between the various mutations in viral core promoter region to different stages of hepatitis B, ranging of asymptomatic carrier state to hepatocellular carcinoma. Am J Gastroenterol 106: 81-92.

Yu H, Yuan Q, Ge SX, Wang HY, Zhang YL, Chen QR, Zhang J, Chen PJ, Xia NS 2010. Molecular and phylogenetic analyses suggest an additional hepatitis B virus genotype "I". PLoS ONE 5: e9297.

Zeng G, Wang Z, Wen S, Jiang J, Wang L, Cheng J, Tan D, Xiao F, Ma S, Li W, Luo K, Naoumov NV, Hou J 2005. Geographic distribution, virologic and clinical characteristics of hepatitis B virus genotypes in China. J Viral Hepat 12: 609-617.

Zhong Y, Lv J, Li J, Xing X, Zhu H, Su H, Chen L, Zhou X 2012. Prevalence, virology and antiviral drugs susceptibility of hepatitis B virus $\mathrm{rtN} 238 \mathrm{H}$ polymerase mutation from 1,865 Chinese patients with chronic hepatitis B. Antiviral Res 93: 185-190.

Zhou B, Wang Z, Yang J, Sun J, Li H, Tanaka Y, Mizokami M, Hou $\mathrm{J}$ 2012. Novel evidence of HBV recombination in family cluster infections in Western China. PLoS ONE 7: e38241. 